\title{
Filigrane
}

Écoutes psychothérapiques

\section{Notices biographiques}

Volume 19, numéro 2, automne 2010

URI : https://id.erudit.org/iderudit/1000464ar

DOI : https://doi.org/10.7202/1000464ar

Aller au sommaire du numéro

Éditeur(s)

Revue Santé mentale au Québec

ISSN

1192-1412 (imprimé)

1911-4656 (numérique)

Découvrir la revue

Citer ce document

(2010). Notices biographiques. Filigrane, 19(2), 123-123.

https://doi.org/10.7202/1000464ar

Ce document est protégé par la loi sur le droit d'auteur. L'utilisation des services d'Érudit (y compris la reproduction) est assujettie à sa politique d'utilisation que vous pouvez consulter en ligne.

https://apropos.erudit.org/fr/usagers/politique-dutilisation/
Cet article est diffusé et préservé par Érudit.

Érudit est un consortium interuniversitaire sans but lucratif composé de l'Université de Montréal, l'Université Laval et l'Université du Québec à Montréal. Il a pour mission la promotion et la valorisation de la recherche. https://www.erudit.org/fr/ 


\section{Notices biographiques}

Carole Bach est psychanalyste, membre de la SSPsa (Société suisse de psychanalyse), psychologue-psychothérapeute membre de la FSP (Fédération suisse des psychologues) et de l'ASP-SPV (Association suisse des psychothérapeutes).

Sylvie Benzaquen est psychologue, psychanalyste, membre du Cercle freudien. Catherine Chabert est psychanalyste, membre titulaire de l'Association psychanalytique de France, et professeure de psychopathologie clinique à l'Université ParisDescartes.

Gilles Chagnon est psychiatre, psychanalyste, chargé d'enseignement clinique à l'Université de Montréal.

François Duparc est membre formateur de la Société psychanalytique de Paris.

Réal Laperrière est psychologue et psychanalyste, membre de la Société psychanalytique de Montréal.

André Lussier est psychanalyste, membre émérite de la Société psychanalytique de Montréal. 